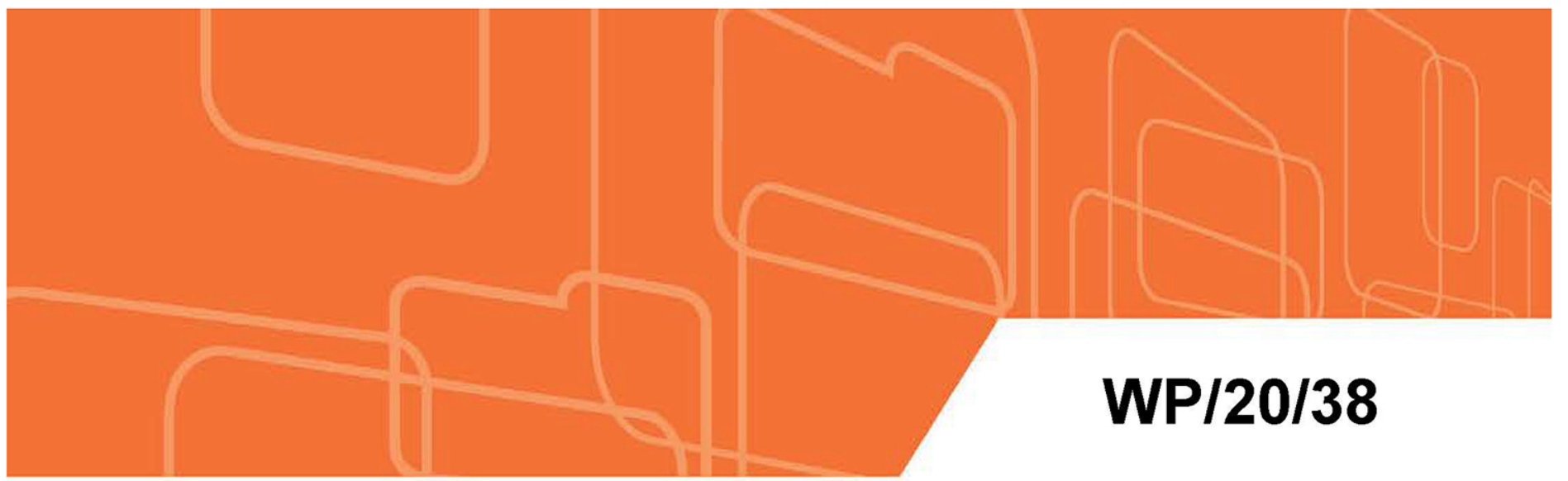

\title{
Labor Costs and Corporate Investment in Italy
}

by Daniel Garcia-Macia

IMF Working Papers describe research in progress by the author(s) and are published to elicit comments and to encourage debate. The views expressed in IMF Working Papers are those of the author(s) and do not necessarily represent the views of the IMF, its Executive Board, or IMF management. 


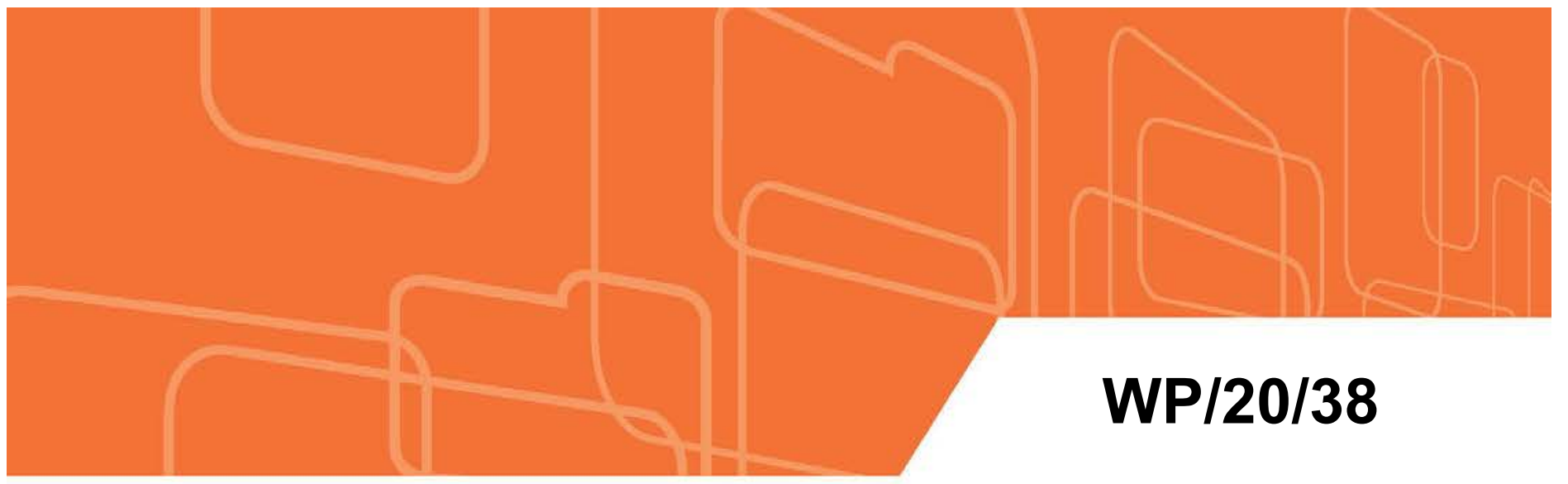

\section{IMF Working Paper}

\section{Labor Costs and Corporate Investment in Italy}

by Daniel Garcia-Macia

IMF Working Papers describe research in progress by the author(s) and are published to elicit comments and to encourage debate. The views expressed in IMF Working Papers are those of the author(s) and do not necessarily represent the views of the IMF, its Executive Board, or IMF management.

I N T E R N A T I O N A L M O N E T A R Y F U N D 


\title{
IMF Working Paper
}

\author{
European Department
}

\section{Labor Costs and Corporate Investment in Italy ${ }^{1}$ \\ Prepared by Daniel Garcia-Macia}

Authorized for distribution by Rishi Goyal

February 2020

\section{IMF Working Papers describe research in progress by the author(s) and are published to} elicit comments and to encourage debate. The views expressed in IMF Working Papers are those of the author(s) and do not necessarily represent the views of the IMF, its Executive Board, or IMF management.

\begin{abstract}
The recovery of private investment in Italy has lagged its euro area peers over the past decade. This paper examines the role of elevated labor costs in hindering the recovery. Specifically, labor costs rose faster than labor productivity prior to the global financial crisis and have remained high since, weighing on firms' profits, capital returns, and thus capacity to invest. Empirical analysis provides evidence for the impact of wages on investment at the sectoral and firm levels. Sectoral wage growth seems unrelated to sectoral productivity growth, but is negatively associated with investment. Firm-level data permit a better identification - by exploiting the interaction between sectoral wage growth (exogenous to the firm) and the lagged labor share of the firm. A 1 percent increase in real wages is estimated to cause a $1 / 3$ percent fall in fixed capital. Profits absorb only $1 / 2$ of the cost increase, pointing to the role of liquidity constraints. These results highlight the need for labor market reform to reinvigorate investment, and thus labor productivity and job creation.

JEL Classification Numbers: J31, G35, G31.

Keywords: labor costs, corporate investment, capital returns, corporate profitability.

Author's E-Mail Address: dgarciamacia@,imf.org

${ }^{1}$ This paper benefited from comments by Rishi Goyal, Fah Jirasavetakul, Alvar Kangur, Chiara Maggi, Nicola Pierri, Raffaele Saggio, Sandro Tomaro, Roberto Torrini, Eliana Viviano and staff at the Italian Ministry of Economy and Finance.
\end{abstract}


TABle OF Contents

CONTENTs

PAGE

I. INTRODUCTION _

II. Aggregate FaCts And Institutional BaCKGround _

A. Aggregate Time Series _

B. Wage Setting in Italy ___

III. THEORY AND EMPIRICAL MODEL__

IV. Micro DAta _

V. EMPIRICAL RESUlts _

A. Sector Level _

B. Firm Level

VI. Aggregate and Policy Takeaways

REFERENCES _

FIGURES

1. Unit Labor Cost, Capital Return and Investment, Non-Financial Corporations

2. NFC Income Uses, Italy $\frac{3}{5}$

3. Labor Cost, Capital Return and Investment, Italy

4. Real Wage Growth by Sector-Year, 2005-2017

5. Elasticity Estimates Under Different Robustness Cases 8

10

TABLES

1. Summary Statistics $\underline{9}$

2. Sector-Level Correlations __ 10

3. Main Regression Results

4. Main Estimated Coefficient by Period, Region, and Firm Size ___

APPENDICES
I. Data
II. Derivations




\section{INTRODUCTION}

Italian real wages have grown faster than labor productivity since Italy joined the euro. Real wage growth since the global financial crisis has stalled, but so has labor productivity. Thus, Italy's unit labor costs remain elevated, even as unit labor costs in Italy's euro area peers have declined. Mounting labor costs appear to have had first-order consequences for Italian firms. National accounts data show that a growing share of labor compensation over value added (i.e. the unit labor cost) has mechanically eroded corporate profits and capital returns (Figure 1). It has also coincided with a decline in corporate investment, especially since the crisis. Although the post-crisis fall in profitability and investment has been ubiquitous in the euro area, it seems to have been exacerbated in Italy by the pressure from elevated labor costs. Depressed investment translates into lower labor productivity, discouraging job creation.

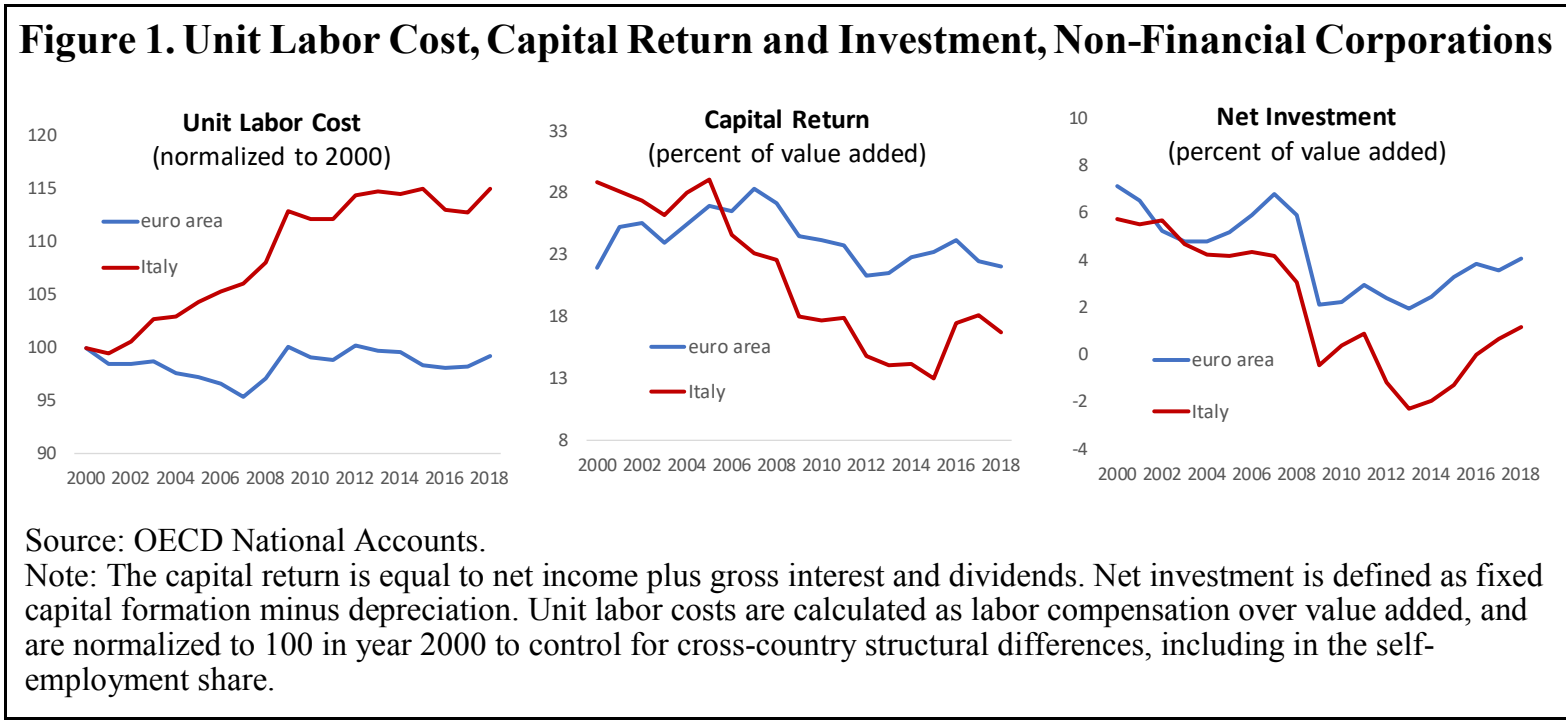

Theoretically, wage increases can negatively affect corporate investment through multiple channels. For example, complementarity between labor and capital in production would predict that a reduction in labor due to a wage hike lowers the marginal product of capital, disincentivizing investment. In addition, a wage hike would tend to reduce firms' cash flow, tightening liquidity constraints and limiting investment capacity. Other theories, such as efficiency wages or substitution of labor for capital, would instead predict a positive relationship between investment and wages.

This paper estimates the impact of wage changes on profitability and investment at the sectoral and firm levels. The estimation uses Orbis firm-level data and data on wage growth by sector for 2005-2017 from the Italian National Statistical Institute (IStat). Sectoral wage growth in Italy, which is determined by national contracts, seems to be unrelated to sectoral productivity growth, consistent with the findings of Boeri et al. (2019), but is negatively associated with investment. Firm-level data permit a better identification of the effects of an increase in wages. Sectoral wage growth is interacted with the lagged labor share of the firm to obtain an exogenous proxy for firm-level labor costs. A panel regression with firm and sector-year fixed estimates that a 1 percent increase in real wages causes a $1 / 3$ percent fall in fixed capital over one year. Profits absorb only $1 / 2$ of the associated cost increase; the rest is passed through to capital formation. 
Given the observed short-term rigidity of labor quantities in Italy, the main channel behind the negative relationship between investment and wages seems to be liquidity constraints - since the factor complementary channel would require labor to fall. In support for this hypothesis, the investment-wage elasticity is estimated to be relatively more negative during the crisis years (2009-2012). Firms in the South and medium firms display lower elasticities than the rest, probably due to the lower effective coverage of national wage contracts in those firms. The main results are robust to changes in the specification and to excluding leading firms in a sector, which could enjoy wage-setting power.

These results suggest that, in the run-up to the global financial crisis, firms offset the impact of rising unit labor costs by borrowing to invest. As firms leveraged up, they were able to contribute to demand growth in the economy but they also became more vulnerable (see Anderson and Raissi, 2018). When credit conditions tightened in the aftermath of the crisis, firms had to cut back on investment. Their capacity to invest has since remained constrained both by the elevated unit labor costs and by their ability and willingness to borrow.

The evidence provided in this paper, therefore, stresses the importance of labor market reforms, as part of an overall package that boosts productivity and hastens the repair of corporate and bank balance sheets. As an illustration, an extrapolation of the regression estimate suggests that correcting the overvaluation in the unit-labor-cost real exchange rate identified in the IMF External Balance Assessment (IMF, 2019b) could bring investment back to its pre-crisis average. Higher investment would boost labor productivity, which would ultimately sustain higher employment and wages. Of course, to the extent complementary reforms (e.g., of product and service markets) credibly raise expected productivity, the scope for such initial wage adjustment would be reduced. Another implication of the results is that labor cost increases would curtail investment. For example, a €9 minimum wage — as was put before Parliament in a draft legislation in 2019—could reduce the fixed capital stock by 0.8 percent.

The paper contributes to the empirical literature studying the response of corporate investment to different types of cost shocks. Regarding labor market policy changes, Calcagnini et al. (2009) and Cingano et al. (2010) estimate that stricter employment protection legislation reduces investment, especially in financially constrained firms, using a panel of European firms. On the other hand, such legislation is found to induce the substitution of labor with capital in withincountry studies of the United States (Autor et al., 2007) and Italy (Cappellari et al., 2012, and Cingano et al., 2015). Daruich et al. (2017) show that enhancing the flexibility of temporary employment in Italy increased firm profits, but they focus mostly on the effects on workers and do not analyze investment. On the financial side, Cingano et al. (2016) identify a negative response of investment to credit supply reductions that constrained the liquidity of Italian firms, in line with the cross-country analysis in IMF (2015). Coibion et al. (2017) find that expectations of higher inflation cause Italian firms to reduce their capital levels. This paper also complements the model-based analysis in Andrle at al. (2018) and Kangur (2018), which quantify the macroeconomic benefits of wage devaluation in Italy, among other structural reforms.

The rest of this paper is organized as follows. Section II presents the aggregate time series on labor costs, capital returns, and investment, and provides an overview of the particularities of the wage setting system in Italy. Section III reviews the theory and proposes an empirical 
model to estimate the relationship between investment and wages. Section IV describes the micro data. Section V discusses the emprirical results and tests their robustness. Section VI concludes with implications for external rebalancing and the impact of minimum wages.

\section{Aggregate Facts and Institutional BaCkground}

\section{A. Aggregate Time Series}

To gauge the magnitude of the macroeconomic trends under study, the aggregate time series are presented first. Using OECD national accounts data, the income uses of non-financial corporations (NFCs) are decomposed into the following categories: employee compensation, depreciation, net interest (equal to interest payment minus interest revenues), distributed dividends, and net income before taxes. These categories approximately sum up to total NFC value added. ${ }^{2}$ Appendix I.A provides the exact variable definitions and shows results for alternative decompositions.

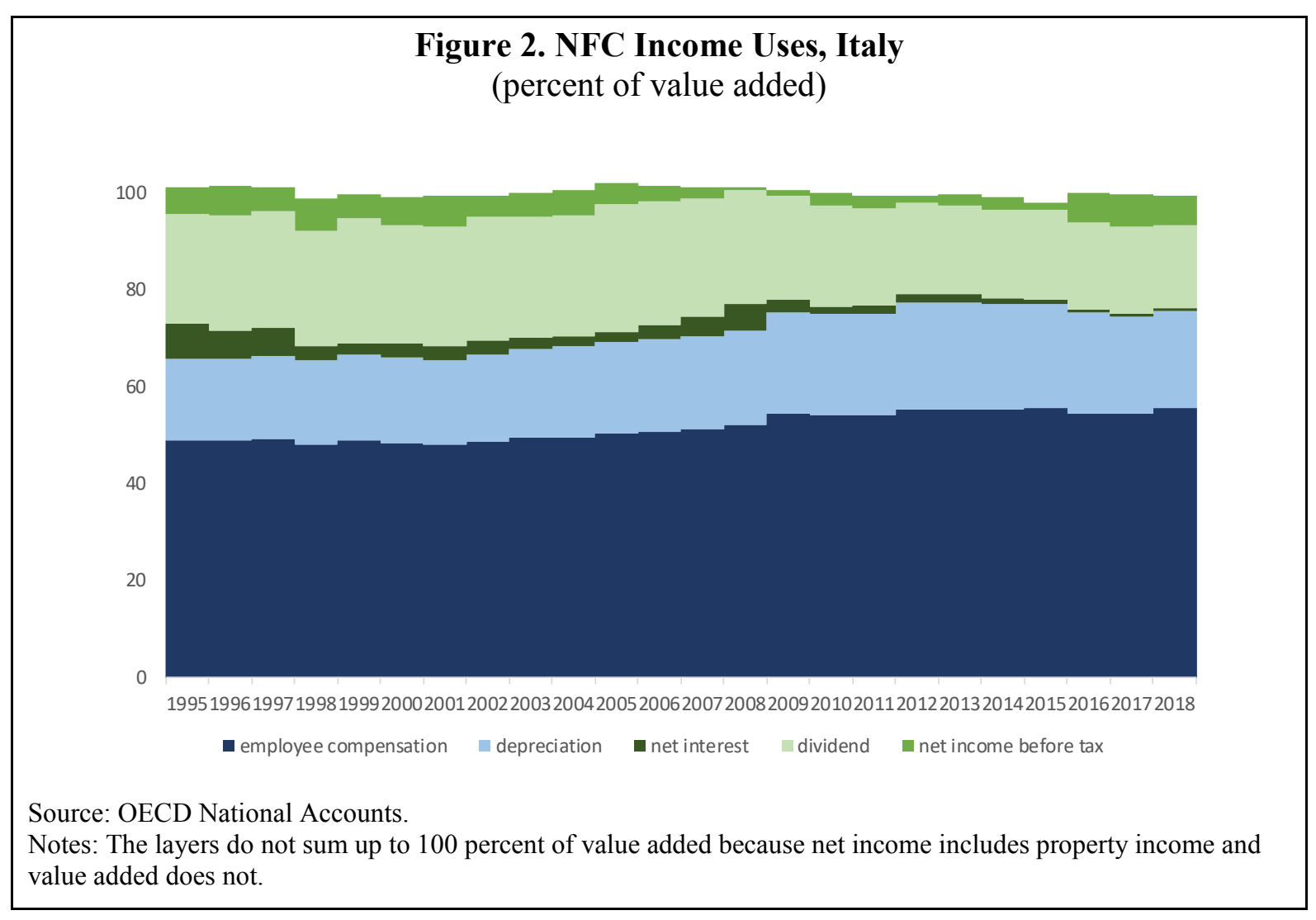

Figure 2 shows that since Italy joined the euro in 2002, the share of value added destined to compensate employees has been on an upward trend. ${ }^{3}$ Together with surging depreciation costs, which mechanically lag the pre-crisis accumulation of capital, this has compressed the net returns to capital — defined as the sum of interest, dividends and profits (or net income

\footnotetext{
${ }^{2}$ The sum is not exact because net income includes property income and value added does not, although this category is tiny relative to total value added.

${ }^{3}$ Employee compensation includes gross wages and social security contributions.
} 
after tax) - especially after the Global Financial Crisis (GFC). In comparison, interest rates, which peaked during the GFC, had a less persistent impact on the combined share of dividends and profits.

Figure 3 shows how the decline in capital returns coincided with a plummeting of investment net of depreciation, suggesting that mounting labor costs may have ultimately limited firms' incentives and/or capacity to invest. Note that average returns in the data are used as a proxy for marginal returns, which should be the variable ultimately determining investment for an unconstrained firm. For a liquidity constrained firm, instead, an additional determinant of investment would be the cash flow, whose evolution is shown in Appendix I.A.

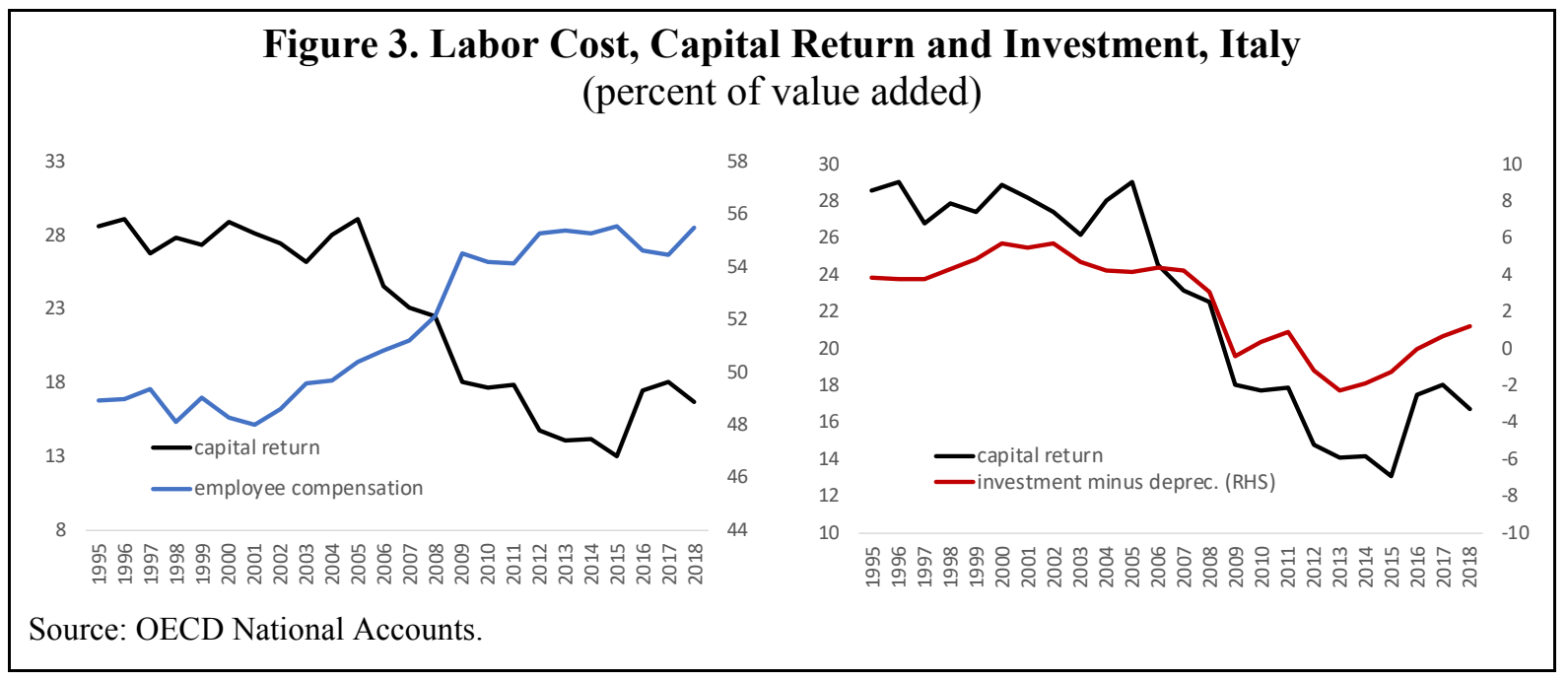

Although capital returns and investment fell across the euro area after the GFC, the trends in Italy were much more pronounced, as previewed in Figure 1 (see also Amici et al., 2018). An important reason could be that the growth of labor costs as a share of value added since 2002 was particular to Italy. In fact, since Italy joined the euro, it has become an outlier in the global trend of diminishing labor shares (Karabarbounis and Neiman, 2013, and Torrini, 2016).

\section{B. Wage Setting in Italy}

The evolution of labor costs in Italy is tied to the characteristics of its wage bargaining system. More than 97 percent of Italian dependent workers are subject to wage contracts negotiated between trade and labor unions at the national level (Contratti Collettivi Nazionale di Lavoro or CCNLs), and thus not determined by individual firms (Boeri et al., 2019). CCNLs set minimum wages for different professional categories (managers, bluecollar workers, etc.) in one or multiple sectors, and typically last for 3 years (source: CNEL contract archive). Although high-productivity firms are allowed to pay firm-level bonuses above the negotiated minimum wage, negotiated minima are set at high enough levels such that they end up binding for about 90 percent of workers (D'Amuri and Giorgiantonio, 2015). Recent measures reducing tax rates on firm-level bonuses and clarifying union representativeness seem not to have led to a visible rise in the use of firm-level bargaining as of 2019. Hence, CCNLs should provide a relevant proxy for effective wage growth. 
Such contract structure has resulted in downwardly rigid nominal wages, which coupled with low inflation, have contributed to the estimated real exchange rate overvaluation in Italy (IMF 2019a and 2019b, and Kangur 2018). Despite a recent expansion in the share of temporary contracts, some of which are remunerated below the CCNL minima, 80 percent of workers are still employed under permanent contracts with relatively high firing costs (Daruich et al., 2017).

\section{THEORY AND EMPIRICAL MODEL}

Theoretically, exogenous changes in wages can affect investment through multiple channels. Two main channels predicting a negative relationship between wages and investment are factor complementarity and financial constraints. Complementarity between labor and capital in production would imply that a reduction in labor due to a wage hike lowers the marginal product of capital, and thus investment. Second, a wage hike tends to reduce a firm's cash flow, which tightens liquidity constraints and limits investment. Conversely, other channels such as efficiency wages or substitution of labor for capital would predict a positive relationship.

The empirical model this paper uses to estimate the response of investment to an exogenous change in wages is grounded on the relationship predicted by a standard production function. Assuming a constant elasticity of substitution demand function for a firm's variety and a Cobb-Douglas production function, capital growth can be expressed as a linear function of the labor share times wage growth:

$$
\frac{\Delta k}{k}=\text { constant }_{1}+\text { constant }_{2} * \alpha * \frac{\Delta w}{w},
$$

where $k$ denotes real capital, $\alpha$ the labor share, and $w$ real wages. Appendix II shows the derivation and the full expression in terms of deep parameters. Here it suffices to note that the term constant $_{2}$ is equal to $1-\sigma$, where $\sigma$ is the elasticity of substitution across varieties. The term constant $_{2}$ is negative for usually estimated parameters (Broda and Weinstein, 2006, estimate $\sigma$ between 3 and 7). That is, exogenous wage growth has a negative effect on capital growth under a Cobb-Douglas production function. ${ }^{4}$

Based on this relationship, the empirical model exploits the fact that negotiated sectoral wage growth in Italy is determined at the national level—and therefore is exogenous to individual firms. ${ }^{5}$ Interacting sectoral wage growth with the firm-level lagged labor share then provides an exogenous proxy for changes in a firm's labor cost. ${ }^{6}$ The firm-level panel regression model is thus specified as:

\footnotetext{
${ }^{4}$ The Cobb-Douglas production function implies an elasticity of substitution between capital and labor equal to 1, while estimates from the literature point to even lower elasticities (Knoblach et al., 2016). A lower elasticity, i.e. stronger factor complementarity, would predict an even more negative response of capital to wages. Hence, although substitution of labor for capital is possible in theory, it is not expected to be the dominating force for the negative relationship on aggregate.

${ }^{5}$ Section V shows the results are robust to excluding leading firms in each sector, which could potentially exert market power in wage setting.

${ }^{6}$ Persistent firm-level shocks affecting both current investment and the lagged labor share could potentially lead to endogeneity. Reassuringly, Section V shows the results are very similar using a two-year lag or an average of years $t-1$ and $t-2$, instead of a one-year lag.
} 


$$
\frac{\Delta k_{i, t}}{k_{i, t-1}}=\beta_{1} \alpha_{i, t-1}+\beta_{2} \alpha_{i, t-1} \frac{\Delta w_{j, t}}{w_{j, t-1}}+\vec{\gamma} X_{i, j, t-1}+\delta_{i}+\delta_{j t}+\varepsilon_{i, t},
$$

where $i$ indexes firms, $t$ time and $j$ sectors. $\beta_{1}, \beta_{2}$ and $\vec{\gamma}$ are coefficients, $X$ is a vector of controls, and $\delta_{i}$ and $\delta_{j t}$ denote firm and sector-year fixed effects, respectively. The controls $X$ include the interaction of interest rate growth and the lagged capital share, mirroring the specification for wages and the lagged labor share, as well as the lagged capital growth rate and other real and financial firm characteristics. The independent error term $\varepsilon_{i, t}$ is mean zero and potentially autocorrelated.

The main coefficient of interest is $\beta_{2}$, which captures the impact of labor cost growth on capital growth. The elasticity of capital growth to wage growth for the average firm is given by $\beta_{2} * \bar{\alpha}$, where $\bar{\alpha}$ is the average labor share across firms. Intuitively, the regression compares firms within a sector in a given year and tests whether those that are more exposed to contractual wage increases (i.e. have a higher labor share) also experience larger declines in their investment relative to their own average over time.

The regression model is also run with cash flow (net income plus depreciation) divided by lagged capital $\frac{c f_{i, t}}{k_{i, t-1}}$ as the dependent variable. Cash flow divided by lagged capital has the same unit as capital growth, and captures the impact of labor costs on a firm before investment decisions are made.

\section{Micro DATA}

Italian firm level panel data are obtained from Orbis for the period 2003-2017. After excluding non-market sectors, state-owned enterprises, one-employee firms, firms in insolvency proceedings, and extreme outliers, an unbalanced sample of around 200,000 firms per year for 2005-2017 remains. The cleaned sample covers $2 / 3$ of NFC value added. Appendix I.B describes the variables and sample in detail.

Data on the average annual growth in negotiated national wage contracts by NACE 4-digit sectors are obtained from IStat for 2005-2017, and merged to the Orbis database at the NACE4 sector-year level. This leaves a total of 221 sectors with more than 20 valid observations in at least two consecutive years. All variables are analyzed in real terms. Macro data on aggregate deflators are obtained from IStat and data on aggregate NFC loan rates are from the Bank of Italy.

Figure 4 shows that contractual real wage growth ranged between -1 and 3 percent across sectors and years, thus providing useful variation to exploit in the regression analysis. Indeed, contractual real hourly wage growth from IStat is confirmed to be a strongly significant determinant of sectoral real growth in labor costs per employee reported in Orbis. Table 1 contains summary statistics for all variables. 
Figure 4. Real Wage Growth by Sector-Year, 2005-2017

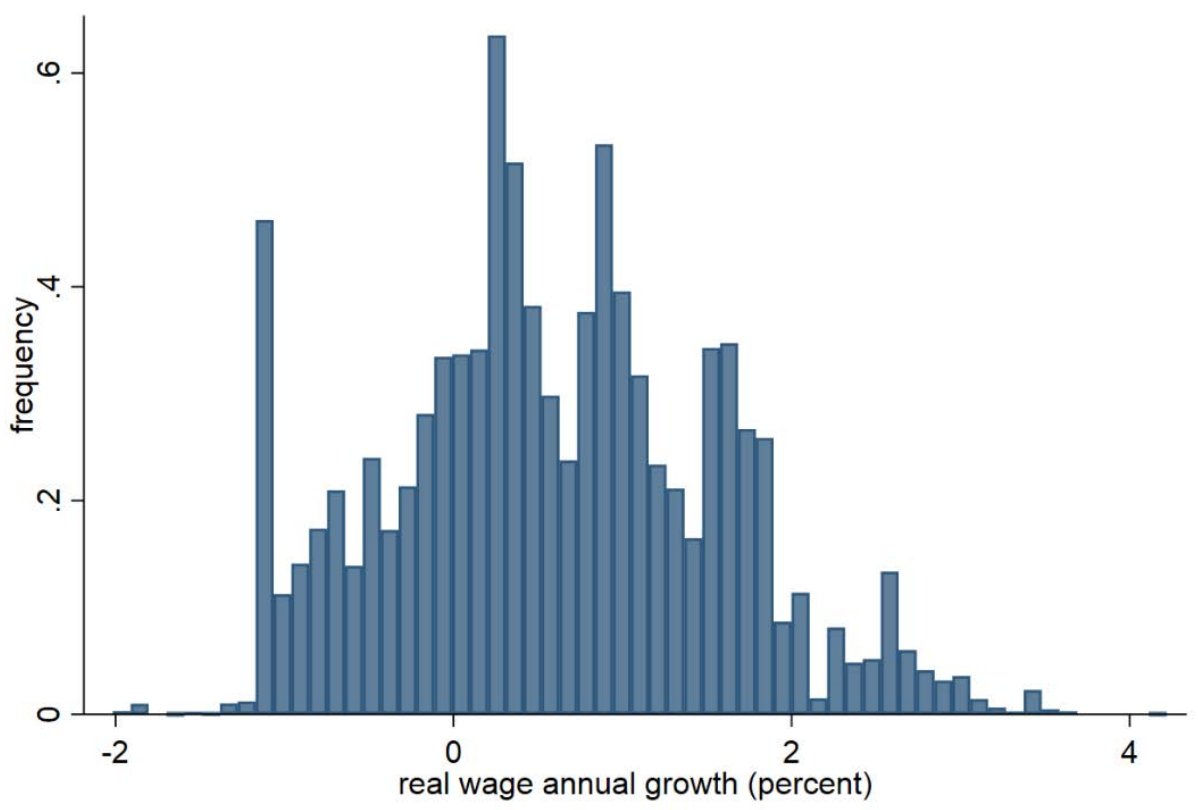

Sources: IStat and Orbis.

Notes: Real wage growth is calculated with the GDP deflator (IStat). The frequency is calculated with Orbis sample weights.

Table 1. Summary Statistics

Variable

Fixed Assets (EUR thousand)

Cash flow (EUR thousand)

Costs of employees (EUR thousand)

Value Added (EUR thousand)

Fixed Asset growth

Cash flow / Lag Fixed Assets

Negotiated wage growth

Lag labor share

Interest rate growth

Lag Debt / Total Assets

Lag Low ICR (dummy)

Number of Employees

age (years)

Sales share in sector

Lag labor share (alternative)
Mean

$10,300,000$

$1,350,024$

$2,250,687$

$4,260,339$

$-0.0086$

0.36

0.0061

0.67

$-0.0022$

0.18

0.47

43.2

20.8

0.0015

0.65
Std. Deviation

$435,000,000$

$45,700,000$

$27,900,000$

$94,000,000$

0.3174

0.39

0.0098

0.18

0.0070

0.19

0.50

533

14.0

0.0105

0.19

Sources: IStat, Orbis and Bank of Italy.

Note: All variables are deflated. Monetary quantities are 2010 euro thousands. 


\section{EMPIRICAL RESULTS}

\section{A. Sector Level}

As a preliminary step, the correlations between wage growth and labor productivity, and wage growth and capital growth, are estimated at the sector level. Table 2 shows that wage growth is unrelated to productivity growth, confirming the result in Boeri et al. (2019). The Italian wage bargaining system seems unable to efficiently adjust wages along this important dimension. This underlines the existence of wedges between negotiated and free-market wages that distort the allocation of labor across firms.

Moreover, sectors with higher wage growth tend to experience significantly lower fixed asset growth, in line with the firm-level results discussed in the next subsection. The elasticity of $3 / 4$ at the sector level is slightly more negative than at the firm level.

\section{Table 2. Sector-Level Correlations}

\begin{tabular}{llrrr} 
dependent var. & regressor & beta & $\mathbf{N}$ & \multicolumn{2}{c}{$\mathbf{R}^{2}$} \\
\hline wage_gr & lab_productivity_gr & 0.004 & 2,745 & 0.000 \\
fixed_asset_gr & wage_gr & $-0.744^{* * *}$ & 2,745 & 0.362 \\
\hline
\end{tabular}

Sources: Orbis and IStat.

Notes: An observation is a sector-year. Asterisks indicate statistical significance at the 10, 5, and 1 percent level respectively. Standard errors are clustered at the sector level. An alternative regression including year FE yields similar results.

\section{B. Firm Level}

\section{Main Regression Results}

The results of the main regressions for investment (fixed asset growth) and cash flow as dependent variables are displayed in Table $3 .^{7}$ The coefficient of interest is the interaction between wage growth and the firm's lagged labor share (highlighted in bold letters). The regressions control for the lagged dependent variable, labor share as a standalone term, the interaction between the capital share (one minus the labor share) and the interest rate on outstanding loans, the debt-to-assets ratio, a dummy indicating whether the interest coverage ratio is below 3 , the log of the number of employees, and the age of the firm (categorized as 0-4, 5-9, 10-14, 15-19, 20-29, 30-39, and 40+ years old).

Multiplying the estimated coefficients of interest $\hat{\beta}_{2}$ by the average labor share across firms and time $\bar{\alpha}=0.67$, a one percentage point increase in wage growth is found to cause a 0.36 percentage point fall in fixed asset growth and a 0.78 percentage point fall in cash flow over capital. That is, firms absorb about half of the increase in their production cost after a wage increase by lowering their profits, and pass through the other half by cutting investment. Both estimates are statistically different from zero at the 5 percent confidence level.

\footnotetext{
${ }^{7}$ The regression is estimated using the procedure in Correia (2017), which allows to efficiently process the large number of fixed effects (Stata command "reghdfe").
} 
Table 3. Main Regression Results

\begin{tabular}{lrr} 
dependent variable: & fixed_assets_gr & cashflow_k \\
\hline L.dep var & $-0.129 * * *$ & $0.166^{* * *}$ \\
L.labor_share & $0.096^{* * *}$ & $0.091^{* * *}$ \\
I_lab_sh*wage_gr & $\mathbf{- 0 . 5 4 1 * *}$ & $\mathbf{- 1 . 1 5 7 * * *}$ \\
1_cap_sh*loan_rate_gr & -0.229 & $2.501^{* * *}$ \\
L.debt/assets & $-0.122 * * *$ & $-0.121^{* * *}$ \\
L.lowICR & $-0.053 * * *$ & $-0.028^{* * *}$ \\
L.log employees & $-0.019 * * *$ & $-0.023^{* * *}$ \\
age bin=2 & $-0.016^{* * *}$ & $0.013^{* * *}$ \\
age bin=3 & -0.001 & $0.018^{* * *}$ \\
age bin=4 & 0.008 & $0.020^{* * *}$ \\
age bin=5 & $0.014 * *$ & $0.022^{* * *}$ \\
age bin=6 & 0.009 & $0.021^{* * *}$ \\
age bin=7 & 0.005 & $0.015^{* *}$ \\
\hline r2_a_within & $2.3 \%$ & $3.3 \%$ \\
N & 888,653 & 844,484 \\
\hline
\end{tabular}

Sources: Orbis, IStat and Bank of Italy.

Notes: Including firm and sector-year fixed effects. The sample excludes one-employee firms, insolvent, SOEs, non-market sectors, and winsorized. Age bin=2 includes firms between 5-9 years old, age bin=3 ages 10-15, etc. All variables are deflated. Standard errors are clustered at the firm level. Asterisks indicate statistical significance at the 10,5 , and 1 percent level respectively. The reported $\mathrm{R}^{2}$ captures within firm fit.

Which theoretical channels explain the negative elasticity of investment to wages? Factor complementarity and/or financial constraints? Tellingly, labor quantities appear to be very rigid with respect to wages, at least at the one-year horizon. A similar regression with employment growth as the dependent variable yields insignificant coefficients (not shown). This is probably a consequence of the relatively high firing costs and the existing subsidy for firms that keep workers on payroll — the system called Cassa Integrazione Guadagni. With employment being relatively rigid, factor complementarity cannot be the main channel, as it relies on labor falling. ${ }^{8}$ Conversely, the large impact of wages on cash flows suggests the potential for liquidity constraints to play a role. This hypothesis is reinforced by the fact that the coefficient of interest is significantly more negative during the global financial and European confidence crises (2009-2012), as shown in Table 4. Even if firms can partially anticipate future growth in real wages, given the triennial nature of nominal wage contracts, liquidity constraints can hinder the optimal adjustment of capital and labor.

Interacting the coefficient of interest with macro-regions (North, Center and South) or firm size groups (categorized as 2-14, 15-199 and 200+ employees) produces interesting results (Table 4). The estimated investment-wage elasticities are significantly weaker for firms in the South and slightly weaker for medium firms. Although this would run against the prior

\footnotetext{
${ }^{8}$ However, part of the explanation could be a fall in the labor utilization rate, which would not be reflected in the reported number of employees.
} 
that liquidity constraints are tighter for those firms, the lower elasticity could in fact be due to the higher prevalence of temporary contracts in such firms, CCNLs covering a smaller share of their workers, or their balance sheet variables being less precisely measured.

\begin{tabular}{|c|c|c|c|}
\hline \multicolumn{4}{|c|}{ Table 4. Main Estimated Coefficient by Period, Region, and Firm Size } \\
\hline dep_var: fixed_asset_gr & Period & region & firm size \\
\hline omitted group & $\begin{array}{c}-0.089 \\
(0.295)\end{array}$ & $\begin{array}{r}-0.649 * * * \\
(0.249)\end{array}$ & $\begin{array}{r}-0.990 * * * \\
(0.335)\end{array}$ \\
\hline crisis (2009-2012) & $\begin{array}{r}-1.044^{* * *} \\
(0.399)\end{array}$ & & \\
\hline Center & & $\begin{array}{r}0.179 \\
(0.160)\end{array}$ & \\
\hline South & & $\begin{array}{r}0.593 * * * \\
(0.168)\end{array}$ & \\
\hline small (2-14 empl.) & & & $\begin{array}{r}0.276 \\
(0.251)\end{array}$ \\
\hline medium (15-199 empl.) & & & $\begin{array}{r}0.647 * * * \\
(0.247)\end{array}$ \\
\hline r2_a_within & $2.3 \%$ & $2.3 \%$ & $2.3 \%$ \\
\hline $\mathrm{N}$ & 888,653 & 888,653 & 888,653 \\
\hline $\begin{array}{l}\text { Sources: Orbis, IStat and Bank of } \\
\text { Notes: The table shows the estima } \\
\text { column respectively are: normal y } \\
\text { below the first row indicate that th } \\
\text { parentheses. }\end{array}$ & $\begin{array}{l}\text { rent groups of firn } \\
\text { d large firms. Sta } \\
\text { different from the }\end{array}$ & $\begin{array}{l}\text { ns. The omitted g } \\
\text { tistically significa } \\
\text { omitted group. S }\end{array}$ & $\begin{array}{l}\text { oups for each } \\
\text { nt coefficients } \\
\text { andard errors are i }\end{array}$ \\
\hline
\end{tabular}

\section{Robustness}

The capital-wage elasticity is estimated under alternative methods to test its robustness. The results are presented in Figure 5. The first column shows the baseline from Table 3 (after multiplying by the average labor share). The second column weights observations by the average real fixed assets of a firm over the period it appears in the sample. Third, the regression is run without controls $(\vec{\gamma}=0)$. Fourth, the interaction between interest rates and the capital share is added to the simple regression in column three. Fifth, the lagged dependent variable is removed from the main regression. Sixth, the lags are taken as an average of the previous two years $(t-1$ and $t-2)$. Using a two-year lag $(t-2)$ gives very similar results. Seventh, firms with a share of sales above 5 percent in a year-sector, which could potentially exert bargaining power in wage negotiations, are excluded. Eighth, the labor share is measured using total factor payments instead of value added as the denominator: $\alpha=\frac{w l}{w l+r^{k} k}$, where the cost of capital $r^{k}$ is equal to the lending rate plus an equity premium approximated to 7 percent. 
Figure 5 shows that estimated elasticities are always negative, mostly ranging from $-1 / 4$ to $-3 / 4$, even though statistical significance is lost in some models. This is due to the vast number of fixed effect parameters (more than 200,000), which absorb most of the variation in the data despite the large sample of firms.

Finally, it would be interesting to analyze dynamics at longer time horizons, including because of potential sluggishness in labor quantities and investment and anticipation of future wage growth by firms. However, the short span of the time series of many of the firms in Orbis would greatly restrict the available sample, risking selection bias.

\section{Figure 5. Elasticity Estimates Under Different Robustness Cases}

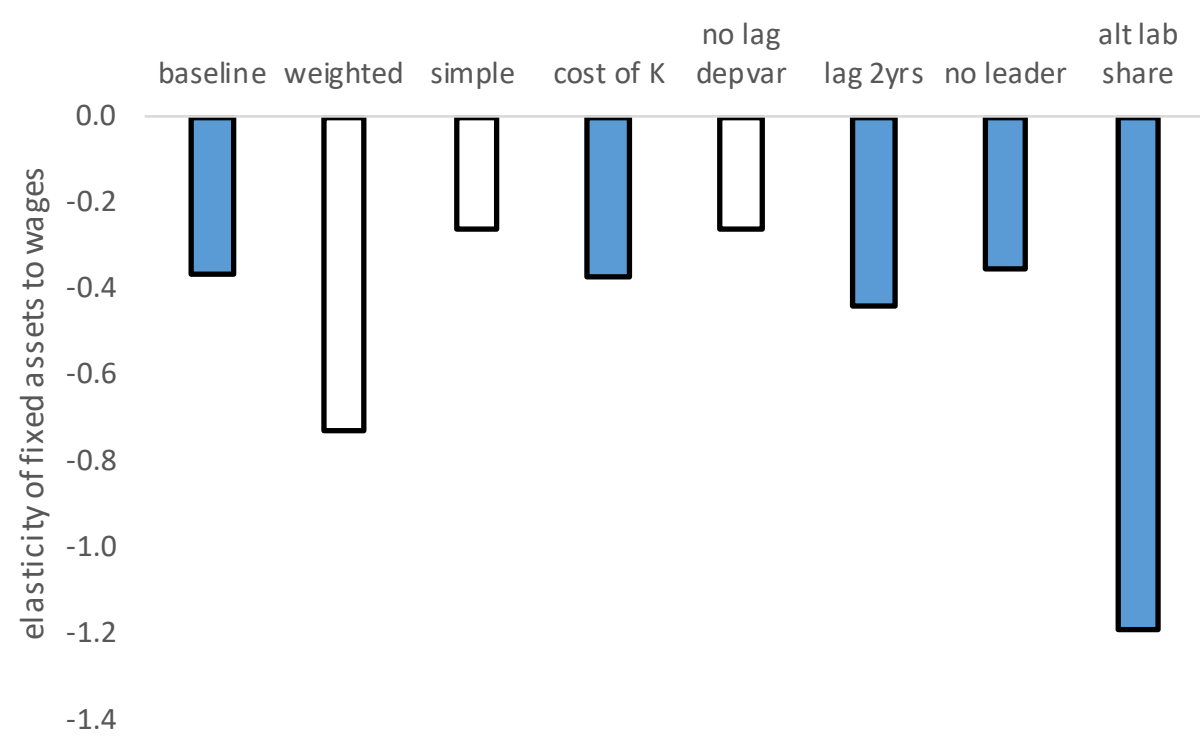

Sources: Orbis, IStat and Bank of Italy.

Note: solid bars indicate statistically significant coefficients at the 95 percent confidence level. Weighted: weighted by fixed assets. Simple: only main regressor. Cost of k: add interaction with interest rate change to simple. No lag depvar: baseline without lagged k growth. Lag 2yrs: average t-1 and t-2 when taking lags. No leader: exclude largest firm in sector-year. Alt lab share: define labor share as a ratio of total factor compensation. Standard errors are clustered at the firm level.

\section{Aggregate and Policy Takeaways}

This paper has shown that mounting labor costs in Italy have constrained capital returns and firm profits, leading to a reduction in fixed capital formation. The empirical evidence supports this conclusion at the aggregate, sector and firm levels. Bearing in mind that regression estimates only capture the partial equilibrium effects of wage changes for an individual firm, this concluding section attempts to extrapolate their implications for some of the macroeconomic and policy challenges faced by the Italian economy: external rebalancing and minimum wage reform. Obviously, such illustrative calculations miss general equilibrium responses, including aggregate demand effects, but are nonetheless helpful to contrast the magnitude of the estimated coefficients in a relevant context. 


\section{External Rebalancing}

The IMF's External Balance Assessment (IMF, 2019b) concluded that Italy's unit labor cost real exchange rate is overvalued by 0 to 10 percent. An illustrative extrapolation of the estimated elasticity suggests that a 6 percent wage devaluation would increase investment over fixed assets by 2.2 percentage points, bringing it back to its pre-GFC average level (from the 2017 level). This result complements the DGSE model-based analysis in Andrle et al. (2018), which predicts that a 15 percent reduction in wage markups in Italy would boost steady-state investment by around 3 percent. Higher investment would translate into higher labor productivity, which would make it possible to expand employment and ultimately raise wages in the steady state.

To the extent that complementary reforms (e.g., of product and service markets) can be implemented to credibly boost productivity, the need for an initial wage adjustment would be reduced. It would also be reduced if the adjustment was not applied uniformly but achieved via a decentralization of the wage bargaining system, since that would disproportionately lower wages in less-productive firms. The resulting improved allocation of labor would yield aggregate efficiency and competitiveness gains.

\section{Minimum Wage}

Several draft bills were presented in Parliament in early 2019 calling for the introduction of a minimum wage. The Italian social security institute (INPS, 2019) estimates that a minimum wage of $€ 9$ per hour would increase labor costs by $€ 9.7$ billion, or 2.2 percent of total labor costs. Using this estimate, an extrapolation of the regression results in this paper suggests that such minimum wage would reduce the fixed capital stock by 0.8 percent.

Beyond the general equilibrium effects discussed above, this prediction is also subject to uncertainty because it is based on the average worker, while the response may be differential across the wage distribution. On the one hand, low-skilled workers, who are more affected by the minimum wage, may be more easily substitutable with capital, which would mitigate (or overturn) the predicted investment impact. On the other hand, the INPS estimate only considers the effects on workers with current wages below the minimum wage level, while a minimum wage could also exert upward pressure on wages above the minimum, pointing to a larger investment decline.

\section{Policy Takeaways}

In sum, correcting wage overvaluation should boost investment, while introducing a minimum wage at an excessive level would harm it. Hence, the results highlight the need for a wage bargaining system that takes into account its impact on investment - specifically, by realigning real wages with labor productivity, for instance, through decentralized wage bargaining. These should be complemented by other decisive reforms, including product market reforms that spur labor productivity and financial policies that strengthen the ability of the banking system to fully support the real economy (IMF, 2019a). A reduction of the labor tax wedge would help reduce labor cost overvaluation and is encouraged in the context of a comprehensive tax reform (Cammeraat and Crivelli, 2020), but would not be sufficient to link wages with productivity at the firm level. 


\section{REFERENCES}

Amici, Monica, Emmanuele Bobbio, and Roberto Torrini. "Patterns of Convergence (Divergence) in the Euro Area: Profitability Versus Cost and Price Indicators." Italian Economic Journal 4, no. 3 (2018): 367-384.

Anderson, Gareth, and Mehdi Raissi. "Corporate indebtedness and low productivity growth of Italian firms”. IMF Working Paper 18/33, 2018.

Andrle, Michal, Alvar Kangur, and Mehdi Raissi. "Italy: Quantifying the Benefits of a Comprehensive Reform Package”, IMF Working Paper 18/60, 2018.

Autor, David H., William R. Kerr, and Adriana D. Kugler. "Does employment protection reduce productivity? Evidence from US states." The Economic Journal 117, no. 521: F189-F217, 2007.

Boeri, Tito, Andrea Ichino, Enrico Moretti, and Johanna Posch. "Wage equalization and regional misallocation: evidence from Italian and German provinces." NBER Working Paper no. 25612, 2019.

Broda, Christian, and David E. Weinstein, "Globalization and the Gains from Variety". The Quarterly Journal of Economics, 121(2):541-585, 2006.

Calcagnini, Giorgio, Germana Giombini, and Enrico Saltari, "Financial and labour market imperfections and investment”, Economics Letters, vol. 102(1), pp. 22-6, 2009.

Cammeraat, Emile, and Ernesto Crivelli, "Toward a Comprehensive Tax Reform for Italy", IMF Working Paper 20/37, 2020.

Cappellari, Lorenzo, Carlo Dell'Aringa, and Marco Leonardi. "Temporary employment, job flows and productivity: A tale of two reforms." The Economic Journal 122, no. 562 (2012): F188-F215, 2012.

Cingano, Federico, Marco Leonardi, Julian Messina, and Giovanni Pica, "The effect of employment protection legislation and financial market imperfections on investment: evidence from a firm-level panel of EU countries", Economic Policy, vol. 25(61), pp. 117-63, 2010.

Cingano, Federico, Marco Leonardi, Julian Messina, and Giovanni Pica. "Employment protection legislation, capital investment and access to credit: evidence from Italy." The Economic Journal 126, no. 595: 1798-1822, 2015.

Cingano, Federico, Francesco Manaresi, and Enrico Sette. "Does credit crunch investment down? New evidence on the real effects of the bank-lending channel." The Review of Financial Studies 29, no. 10: 2737-2773, 2016.

Coibion, Olivier, Yuriy Gorodnichenko, and Tiziano Ropele. "Inflation expectations and firm decisions: New causal evidence.” NBER Working Paper no. 25412, 2018. 
Correia, Sergio, "Linear Models with High-Dimensional Fixed Effects: An Efficient and Feasible Estimator” Working Paper. http://scorreia.com/research/hdfe.pdf, 2017

D'Amuri, Francesco, and Cristina Giorgiantonio. "The institutional and economic limits to bargaining decentralization in Italy”. IZA Policy Paper no. 98, 2015.

Daruich, Diego, Sabrina Di Addario, and Raffaele Saggio. "The effects of partial employment protection reforms: Evidence from Italy." Mimeo, Princeton University, 2017.

Kangur, Alvar. "Competitiveness and Wage Bargaining Reform in Italy", IMF Working Paper 18/61, 2018.

Karabarbounis, Loukas, and Brent Neiman. "The global decline of the labor share." The Quarterly Journal of Economics, 129.1: 61-103, 2013.

Knoblach, Michael, Martin Rößler, and Patrick Zwerschke. "The elasticity of factor substitution between capital and labor in the US economy: a meta-regression analysis." CEPIE Working Paper no. 03/16., 2016.

International Monetary Fund, World Economic Outlook, Chapter 4: "Private Investment: What's the Holdup?", April 2015.

IMF, Italy: 2018 Article IV Consultation Staff Report, 2019a.

IMF, 2019 External Sector Report, 2019b.

INPS, XVIII Rapporto annuale, July 2019.

Torrini, Roberto. "Labour, profit and housing rent shares in Italian GDP: long-run trends and recent patterns." Bank of Italy Occasional Paper 318, 2016. 


\section{ApPendix I. DAta}

\section{A. National Accounts}

\section{Variable Definitions}

Table A.1 contains the variable definitions used to decompose NFC income uses data from OECD national accounts.

\begin{tabular}{|ll|}
\hline \multicolumn{2}{|c|}{ Table A.1. National Account Variable Definitions } \\
Concept & Formula (OECD variable codes) \\
\hline Value added & NFB1GR \\
Employee compensation & NFD1P \\
Depreciation & NFK1R \\
Net interest & NFD41P - NFD41R \\
Dividend & NFD42P \\
Net income before tax & NFB5GP - NFK1R \\
Net tax & NFD2P + NFD5P + NFD6P + NFD9P - NFD3R - NFD6R - NFD9R \\
Net income & Net income before tax - Net tax \\
Capital returns & Net income + Dividend + NFD41P - NFD3R - NFD6R - NFD9R \\
Net investment & NFP51P - Depreciation \\
Cash flow & Net income + Depreciation \\
\hline
\end{tabular}

\section{Alternative Decompositions}

Alternative decompositions of the national accounts data are shown next. Figure A.1 replicates Figure 2 decomposing net income before taxes into net taxes (taxes minus subsidies) and net income. It shows that the higher net tax burden since 2007 contributed to squeeze net profit margins, beyond the effect of rising labor costs, albeit by a smaller amount.

Figure A.2 replicates Figure 3 showing cash flow instead of capital returns. Average capital returns are a proxy for the marginal return to capital, which should determine investment for unconstrained firms, but the cash flow is a more relevant measure for liquidity constrained firms. Cash flow followed a similar trend as capital returns, but recovered more vigorously since 2016. 
Figure A.1. NFC Income Uses, Disaggregating Taxes, Italy

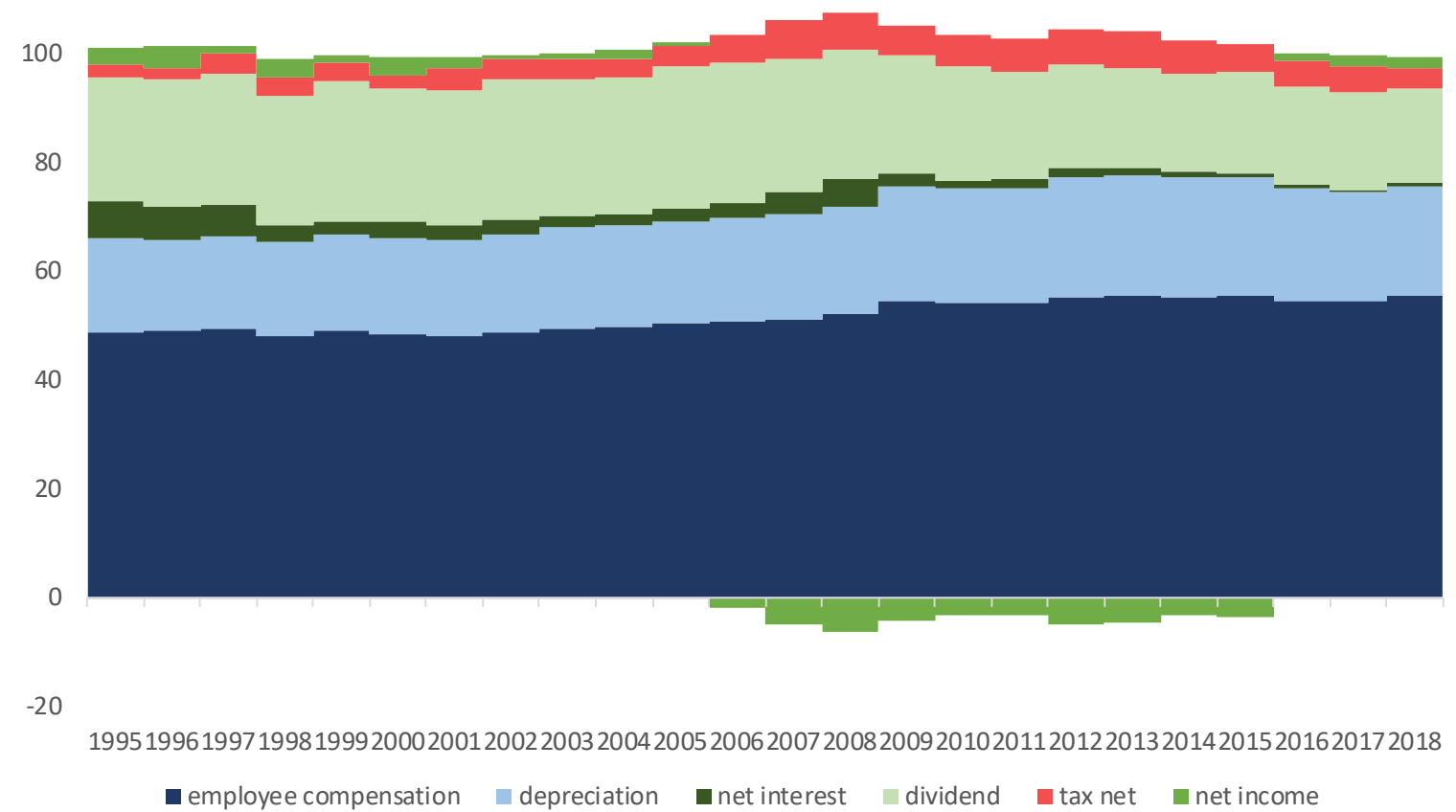

Note: The layers do not sum up to 100 percent of value added because net income includes property income and value added does not. Net taxes are equal to taxes paid minus subsidies received.

Source: OECD National Accounts.

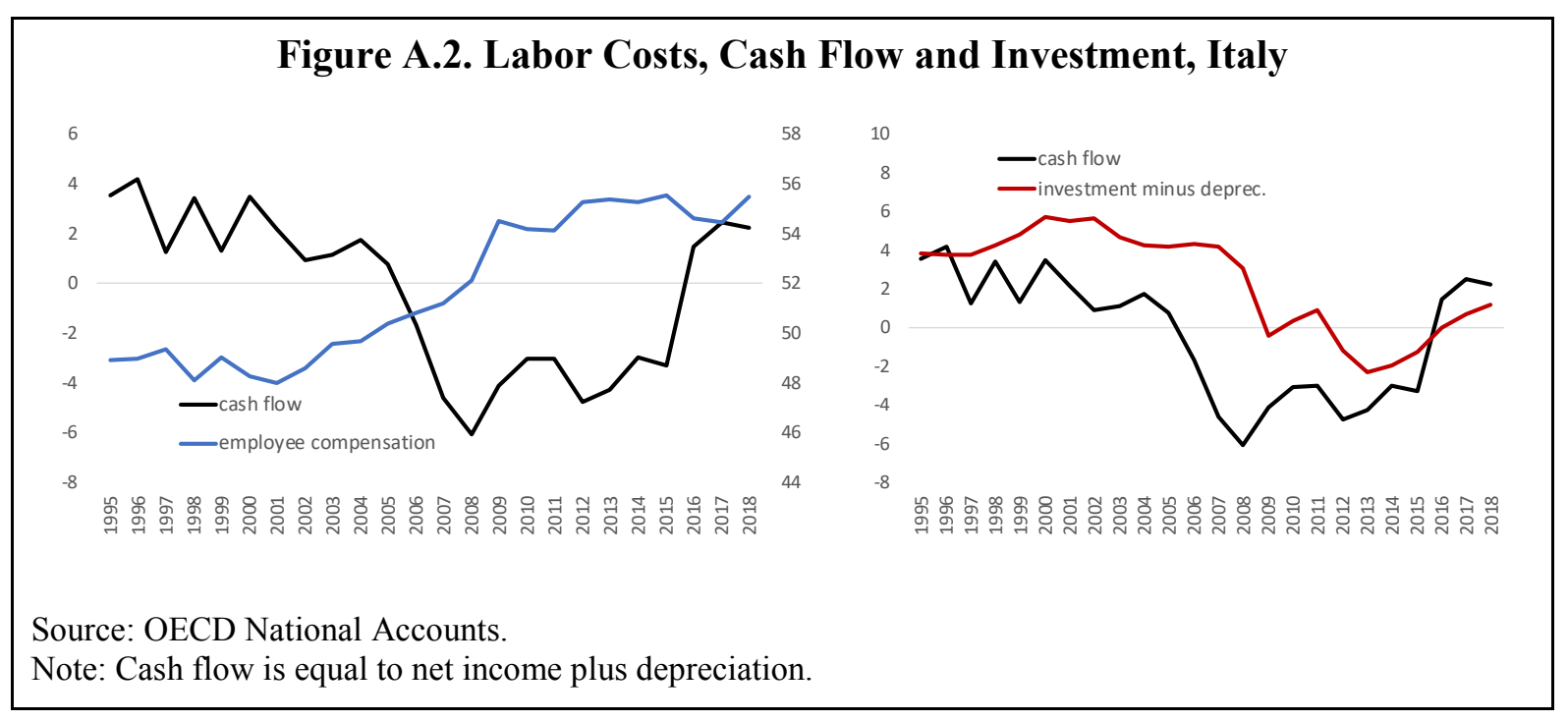




\section{B. Firm-Level Data}

\section{Variable Definitions}

Table B.1 contains the variable definitions in Orbis.

\begin{tabular}{|c|c|}
\hline \multicolumn{2}{|r|}{ Table B.1. Orbis Variable Definitions } \\
\hline Concept & Formula (Orbis variable names) \\
\hline Labor share & Costs_of_employees / Added_value \\
\hline Capital share & 1 - Labor share \\
\hline Debt & Loans + Long_Term_Debt \\
\hline Firm age & (Closing_date - Date_of_incorporation) / 365.25 \\
\hline Labor share (alternative) & Costs_of_employees / \\
\hline & $($ Costs_of_employees $+($ rrate_outstanding +0.07$) *$ Total_Assets $)$ \\
\hline
\end{tabular}

\section{Sample}

Constructing the estimation sample with Orbis, Istat, and Bank of Italy data involves two steps. First, the following firm-year observations in Orbis are excluded: ${ }^{1}$

- $\quad$ non-market sectors: agriculture, mining, financials, real estate, public administration and extraterritorial bodies

- $\quad$ insolvent firms: any firm status other than "Active" or "Active (default of payment)"

- $\quad$ state-owned enterprises: the controlling shareholder is classified as "Public authority, state, government"

- duplicate consolidated accounts (C2 category in Orbis)

- $\quad$ non-positive fixed assets, cash flow, value added or age

- $\quad$ one or less employees

- $\quad$ fixed asset growth above 100 percent or below -50 percent, either for contemporaneous or lagged variable

- $\quad$ cash flow over fixed assets below 200 percent, either for contemporaneous or lagged variable

\footnotetext{
${ }^{1}$ The sample construction procedure benefited from code by Anderson and Raissi (2018).
} 
- $\quad$ lagged labor share is smaller than 10 percent or bigger than 99 percent

- $\quad$ debt over total assets is above 95 percent

- $\quad$ year-sector cluster has less than 20 observations

- for sector-level regressions: drop sectors whose yearly productivity growth is outside the -20 to 20 percent range or whose capital growth is outside the -30 to 50 percent.

Small modifications of the above thresholds do not change the results substantially.

Second, the remaining Orbis data are merged with data on negotiated wages by sector (Istat variable: "hourly index of wages according to collective labour agreements (Nace rev.2)") at the 4-digit NACE - year level, and with deflators (IStat) and interest rates on NFC outstanding loans (Bank of Italy) by year. 


\section{APPENDIX II. DERIVATIONS}

This appendix derives the reduced-form relationship between capital growth and wage growth presented in Section III (equation (1)).

Let firm varieties be aggregated with a constant elasticity of substitution (CES) function:

$$
Y=\left(\sum_{i}\left(y_{i}\right)^{\frac{\sigma-1}{\sigma}}\right)^{\frac{\sigma}{\sigma-1}}
$$

where $y_{i}$ is the output of firm $i$ and $\sigma>1$ is the elasticity of substitution across firms.

Consumer optimization implies the following inverse demand function for varieties:

$$
p_{i}\left(y_{i}\right)=P\left(\frac{y_{i}}{Y}\right)^{-\frac{1}{\sigma}} .
$$

Let $y$ be produced with a Cobb-Douglas production function in capital $k$ and labor $l$ :

$$
y=k^{1-\alpha} l^{\alpha},
$$

where $\alpha \in(0,1)$ is the labor share.

Firms maximize revenues $p(y) * y$ choosing capital and labor and taking as given gross interest rates $r$ and wages $w$. The first order conditions for capital and labor are, respectively:

$$
\begin{gathered}
P Y^{\frac{1}{\sigma}} \frac{\sigma-1}{\sigma} y^{\frac{\sigma-1}{\sigma}} \frac{1-\alpha}{k}=r, \\
P Y^{\frac{1}{\sigma}} \frac{\sigma-1}{\sigma} y^{\frac{\sigma-1}{\sigma}} \frac{\alpha}{l}=w .
\end{gathered}
$$

Taking growth rates and rearranging the first order conditions yields equation (1) in terms of deep parameters:

$$
\frac{\Delta k}{k}=-(\sigma-1) \alpha * \frac{\Delta w}{w}-(\sigma+(\sigma-1)(1-\alpha)) * \frac{\Delta r}{r} .
$$

Note that the constants multiplying wage growth and interest rate growth are both negative. 